\title{
Cost-Effective Drainage Performance Assessment and Field Management Options for Sustainable Environmental Management Under Irrigated Agriculture of Ethiopia
}

\author{
Ashebir Haile Tefera \\ Ethiopian Institute of Agricultural Research (EIAR), \\ Debre Zeit Agricultural Research Center, P.O.Box. 32, Debre Zeit, Ethiopia
}

\begin{abstract}
Irrigation is one of the means by which agricultural production can be increased to meet the growing food demands of the fast-growing population of the country and satisfy the country's economic demand. However, poor irrigation water management, and lack of proper implementation of drainage systems, substantial numbers of Irrigation schemes especially in potentially susceptible areas are starting to suffer from these problems. The aim this study is to assess a cost effective drainage performance and field management options under hot spot area irrigated agriculture of Ethiopia. It has been observed that inadequate attention to drainage aspects of irrigation due to the absence of sound objective is challenging this untapped sub-sector and also unsustainable water management practices and limited technical and institutional capacity to expand and manage irrigation infrastructure is one of the prioritized bottlenecks. The result also revealed that salt affected surfaces have increased from $6 \%$ to $16 \%$ of the total land of Ethiopia in recent years. About $9 \%$ of the population lives in the areas affected by salinity. The semi-arid and arid lowlands and valleys in Ethiopia have major problems of salinity and alkalinity. About 44 million ha in $36 \%$ of the country's total land is potentially susceptible to salinity problems. According to recent researches, out of the 44 million ha, 33 million ha has dominantly salinity problems, 8 million ha has combined salinity and alkalinity problems, and 3 million ha has dominantly alkalinity problems. The majority of schemes (small, medium, and large), poor drainage facilities, and water management practices, hence, give low yields (quite below the national average) with poor crop quality, and environmental damage. Such a very low yield, poor crop quality and salinity could be attributed to poor drainage system at plot or scheme's level. It is evident that poor management of agricultural water management will play a significant role in poor drainage and salinity incidence. Therefore, there should be well organized and proper water management in the irrigated field.
\end{abstract}

Keywords: Drainage, salinity, water management, schemes and crop quality.

DOI: $10.7176 / J R D M / 71-01$

Publication date: November $30^{\text {th }} 2020$

\section{Introduction}

Agriculture is the basis for the entire socio-economic structure of Ethiopia and has a major influence on all other economic sectors and development processes. Reports indicated that agriculture accounts for $38.8 \%$ of the total GDP with more than $80 \%$ total labor employment, contributing to about $78.5 \%$ of export shares and crucial for input provision to growing agro-food manufacturing industry and supplies the much needed raw material for the agro-processing and manufacturing sector [1]. The Government emphasized the priority given to agricultural development through its Agricultural Development Led Industrialization (ADLI) strategy focusing on the development of agriculture as a source of production for direct consumption, raw materials for industrial use as a major source of consumer products coming out from the industrial sector and for foreign currency earnings [2]. Our premise is that well-managed irrigation development is key in helping Ethiopia overcome major challenges including population pressure; soil and land degradation; high climate variability, and low agricultural productivity [1, 3-6]. In addition, agricultural water development and management is crucial to improve smallholder livelihood and income in Ethiopia, since irrigation can help farmers increase their crop production, increase crop variety, and lengthen their agricultural seasons. Rainfall in Ethiopia is highly erratic, and most rain falls intensively, often as convective storms, with very high rainfall intensity and extreme spatial and temporal variability [7]. The result is that there is a very high risk of annual droughts and intra-seasonal dry spells which put rain-fed agriculture at risk and unreliable, thus jeopardizing food security in the country.

Ethiopia has large water resources that could be used for a wide range of irrigation developments. It has 12 river basins with an annual water runoff volume of over 122 billion $\mathrm{m} 3$. In addition, there is a huge potential of groundwater annually rechargeable resource $[4,8]$. Nowadays $[4,9,10]$, the Ethiopian government gives special attention to irrigation development and aggressively expands it by smallholder farmers' level. The vision statement of the national smallholder irrigation and drainage strategy is "Transforming agricultural production from its dependence on rain-fed practices by creating a vibrant irrigation sector in which smallholder farmers/agropastoralists have access to at least one option of the water source to increase production and productivity as well as enhance resilience to climate change and thereby sustain growth, ensure household food security and maintain 
increasing house hold incomes." It is estimated that only about $15-20 \%$ of the irrigation potential of about 11.1 million hectares of land is under irrigation $[4,5,8,9]$. However, for a number of reasons the irrigation sector has not yet played a major role to cover the imbalance between food demand and supply, to benefit farmers and generate jobs for the youth $[7,11]$.

Irrigation is one of the means by which agricultural production can be increased to meet the growing food demands of the fast-growing population of the country and satisfy the country's economic demand. The Increasing demand for food can be met in one or a combination of three ways: (i) increasing agricultural yield, (ii) increasing the area of arable land, and (iii) increasing cropping intensity by growing two or three crops per year using irrigation. However, expansion of the area under cultivation is a limited option, and hence, increasing yields through cropping intensity system in irrigated areas with various mitigation methods and technologies are the most viable options for achieving food security in the shortest time span. Meanwhile, salinity, sodicity, waterlogging, and other similar incidents are becoming an emerging challenge for irrigation development [12-14]. Due to poor irrigation water management and lack of proper implementation of drainage systems, substantial numbers of Irrigation schemes especially in potentially susceptible areas are starting to suffer from these problems [15, 16]. Inadequate attention to drainage aspects of irrigation due to the absence of sound objective is challenging this untapped sub-sector. Unsustainable water management practices and limited technical and institutional capacity to expand and manage irrigation infrastructure is one of the prioritized bottlenecks.

The importance of drainage to combat salinity or waterlogging is basically not evident for users in irrigated areas. Subsurface drainage functioning is not so easy to perceive by the farmers. The image of drainage is even negative as "it removes water from the soil" and its effects appear opposite to those of irrigation. Failures of irrigation services are rather easy to detect whereas those of drainage is not obvious. In addition, the consequences of drainage under-performance must be assessed in the medium-long term while those of irrigation are immediate and clearly observed in the crop development.

Therefore, in order to overcome these problems and achieve the expected target/output creating awareness on rolling environmental damage in irrigated agricultural land due to poor water management practices as well as to equip the irrigators \& irrigation expertise on different management practices including the design and implementation cost-effective drainage systems and management options is so vital. Therefore, the main objective of this study is to identify the cost-effective drainage technology and management option on farm which is caused due to poor water management practices and costly environmental damages.

\section{Methodology}

\section{a. Preliminary Data}

Climatic data

Different regimes of rainfall are classified according to their 'shape' and 'magnitude' variation over space [17] The 'shape' classification identifies the similar form of rainfall distribution regardless of the absolute magnitude. It can be defined in terms of the seasonality index (SI) and the frequency classes of the rainfall period of the year. The most useful description of the frequency of rainfall regimes was prepared by National Metrology Agency (NMA), which divided the country into four rainfall classes, mono-modal, which receives one rainy season in the year, Bi-modal Type I., Bi-modal Type II, which receive one short and one long rainy season and two distinct rainfall seasons in the year, respectively [18] and Diffused pattern. 


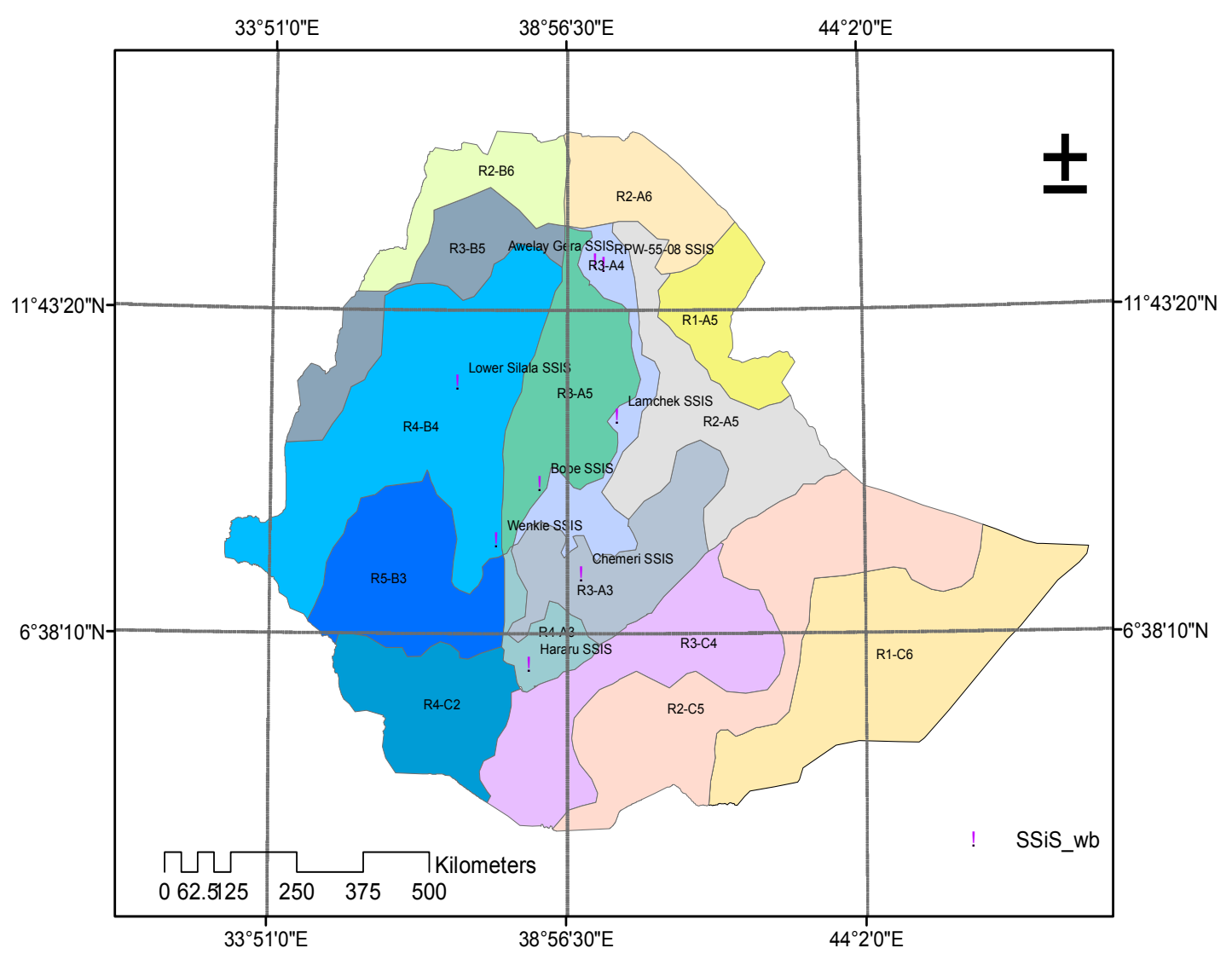

Figure 1. Class of rainfall regime of Ethiopia.

Nevertheless, these rainfall regime classifications don't consider the magnitude, duration, timing, and frequency of rainfall. As a result, [11] reviewed and presented 15 rainfall regime classifications (figure 1) for Ethiopia.

\section{Potential Irrigable land in Ethiopia}

According to the then Ministry of Water Resources [7, 8, 19, 20], it is identified 560 irrigation potential sites on the major river basins. The total potential irrigable areas based on the identified 560 irrigation potential sites is around 3,506,938 ha (figure 2). 


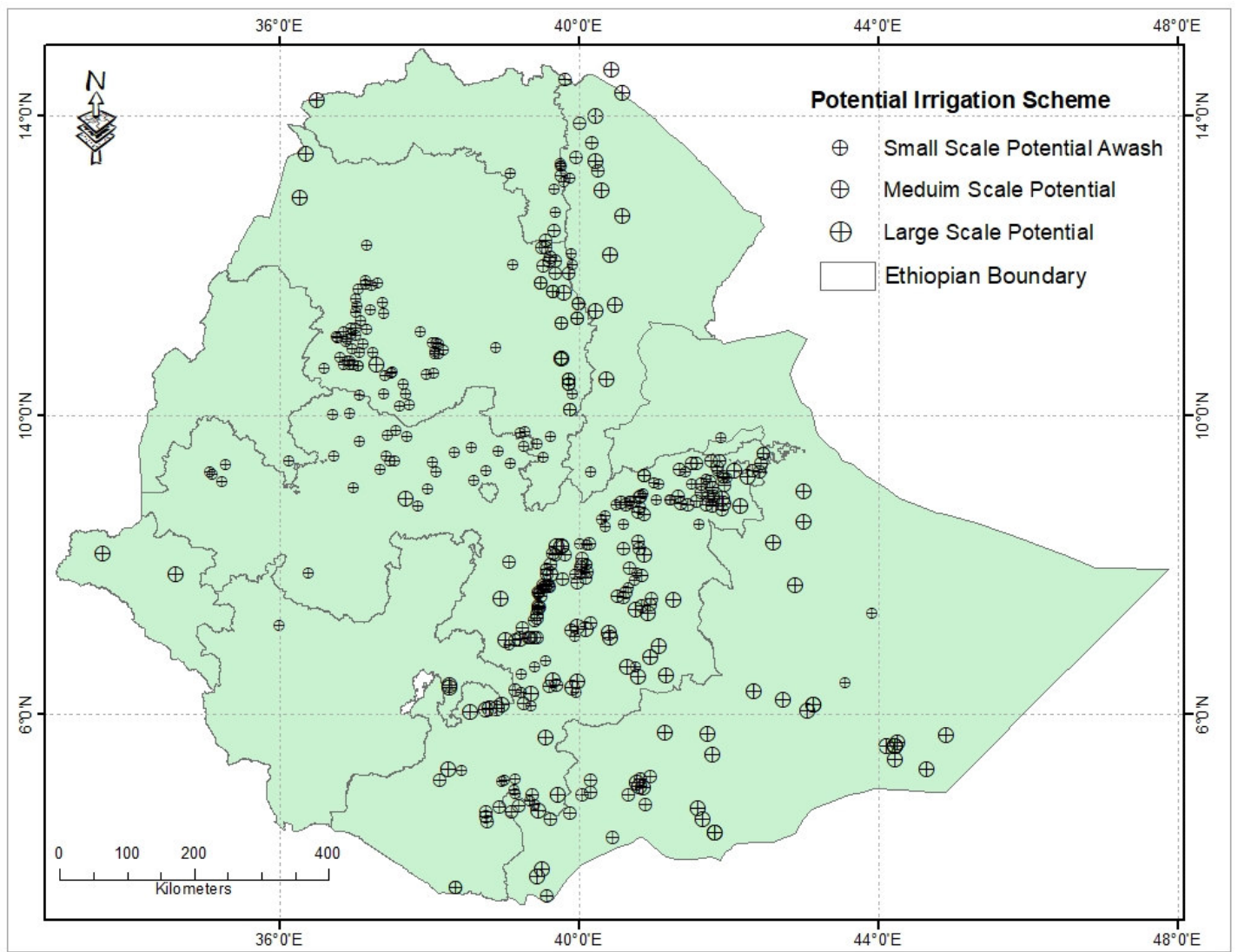

Figure 2. Irrigation potential of Ethiopia.

Many authors such as $[1,4,7,8]$ were used government based irrigation schemes classification systems for their description during their studies. According to Ministry of Water Resources of Ethiopia ([21], irrigation development in Ethiopia is classified based on the size of the command area, in three types: Small-scale irrigation systems ( $<200$ hectares ha), Medium-scale irrigation systems (200-3,000 ha) and Large-scale irrigation systems $(>3,000 \mathrm{ha})$. This classification system is the most common in Ethiopia. Accordingly, $46 \%$ of proposed irrigation developments are in the small-scale irrigation category (Makombe et al., 2011).

\section{Existing Irrigation Development}

Irrigation development is vital to the sustainable and reliable agricultural developments in Ethiopia [22]. According to the data collected from the then Ministry of Water Resource of Ethiopia, 791 schemes have been gathered from different regional states of Ethiopia. 


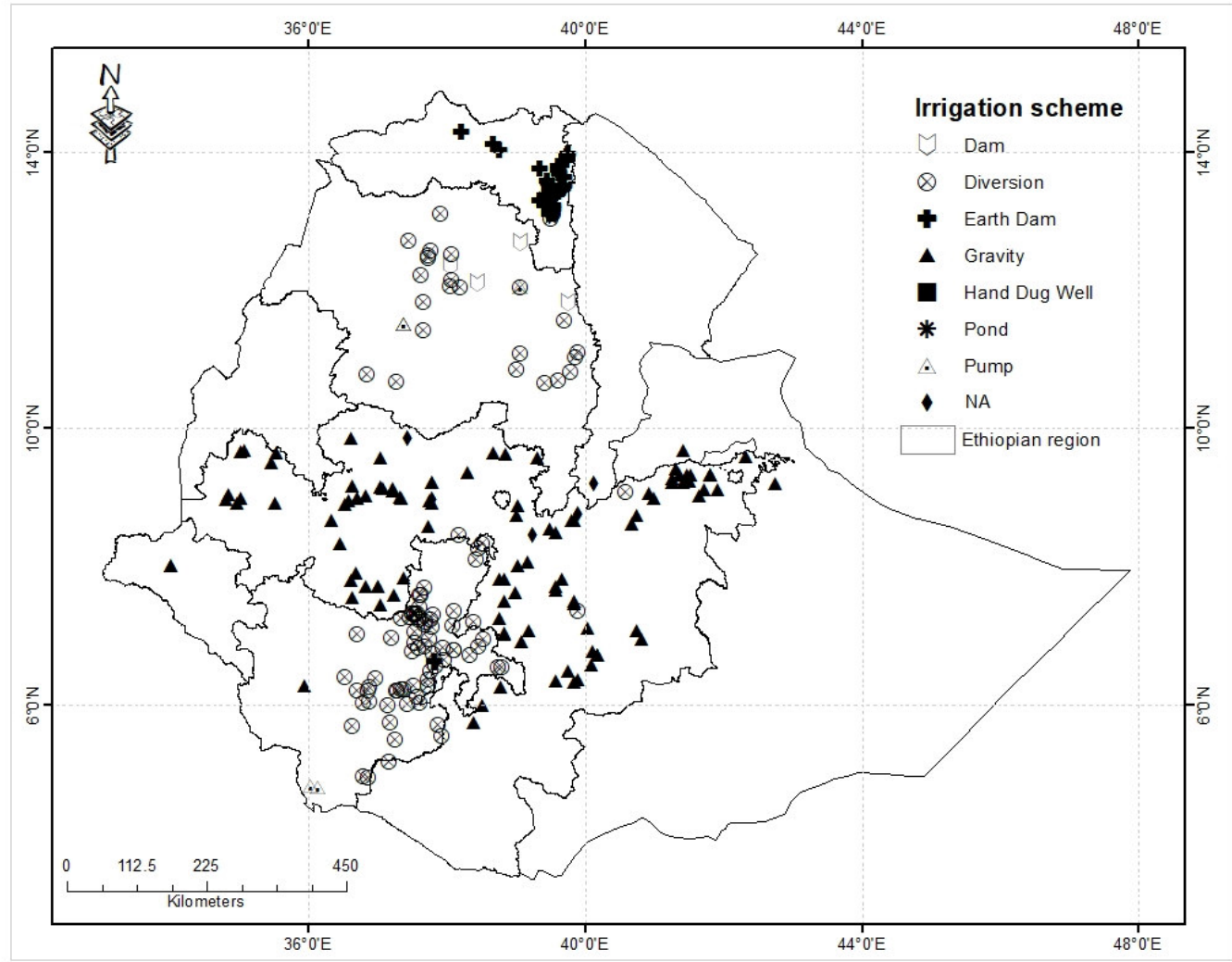

Figure 3. Existing irrigation in Ethiopia.

According to the data, the total estimated area of irrigated agriculture in the country is $107,265.65$ hectares out of which 20,038.39 hectares is from small-scale, 30,291.26 hectares is from medium-scale and 56,936 hectares is from the large scale.

\section{Scope of Drainage Performance Assessment}

Performance assessment is an essential part of management. Each organization ought to have objectives and means to achieve them (Figure 4) and it is essential for it to assess how these objectives are fulfilled (effectiveness) and how its means and resources are utilized (efficiency).

objectives

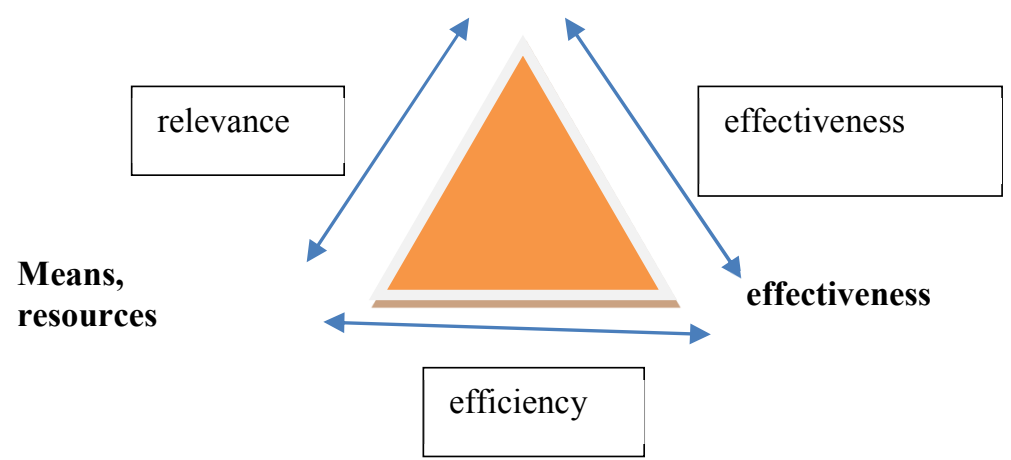

Figure 4. Management performance assessment.

The management triangle Performance Assessment and Potential Indicators (Figure 4) for Drainage Systems can be defined and assessed from a variety of perspectives. It is :

$>$ the degree to which an organization's products and services responds to the needs of their customers or

$>$ the degree with which the organization uses the resources at its disposal (both strategic and operational, or

$>$ the degree to which the systems comply with the design criteria (technical).

Applied to drainage, operational performance refers to the level of compliance of a system with its design criteria while strategic performance refers to its outputs, which are not necessarily only the result of the drainage 
system performance $[23,24]$. Operational assessment can be regional or very site-specific and in the latter case, detailed technical design criteria are used for indicator values. In practice, at the field level, operational performance is related to proper removal of surface water, after rainstorms, or irrigation application and/or with proper control of the water table levels [25]. At the system level, it is related to the proper removal of the water discharged from the fields. Strategic performance is related to the different roles of drainage in increasing and regulating crop production. It encompasses salinity control in the root zone, contribution to rural development, and drainage effects on health and environment. At a technical and operational level, a simple direct indicator such as water table behavior in time, or water table depth considered spatially at certain critical periods, is generally sufficient.

\section{a. Preliminary Investigations (First Step)}

The preliminary investigation will include site observation, agricultural production system, vegetation cover, land degradation, irrigation water sources, settlements, etc. Based on size of land holding, topography and soil type, the sampling site and grid size will be determined. This first step is proposed to include the following four activities:

i. Complaint management.

ii. File/database search: this includes the age of the project together with the applied technology (materials and construction methods); the applied quality control; the contract documents; and other indications may be included and each indication may have value singularly or in combination with others.

iii. Agricultural data search: crop productivity and cropping pattern.

The min criteria should base potential crop producing locations and also cropping pattern and intensification. The agricultural data consists of a type of plant to plot size and farm area and extends to regoins and country irrigated area. This is highly driven by time versus space as indicated in figure 5 .

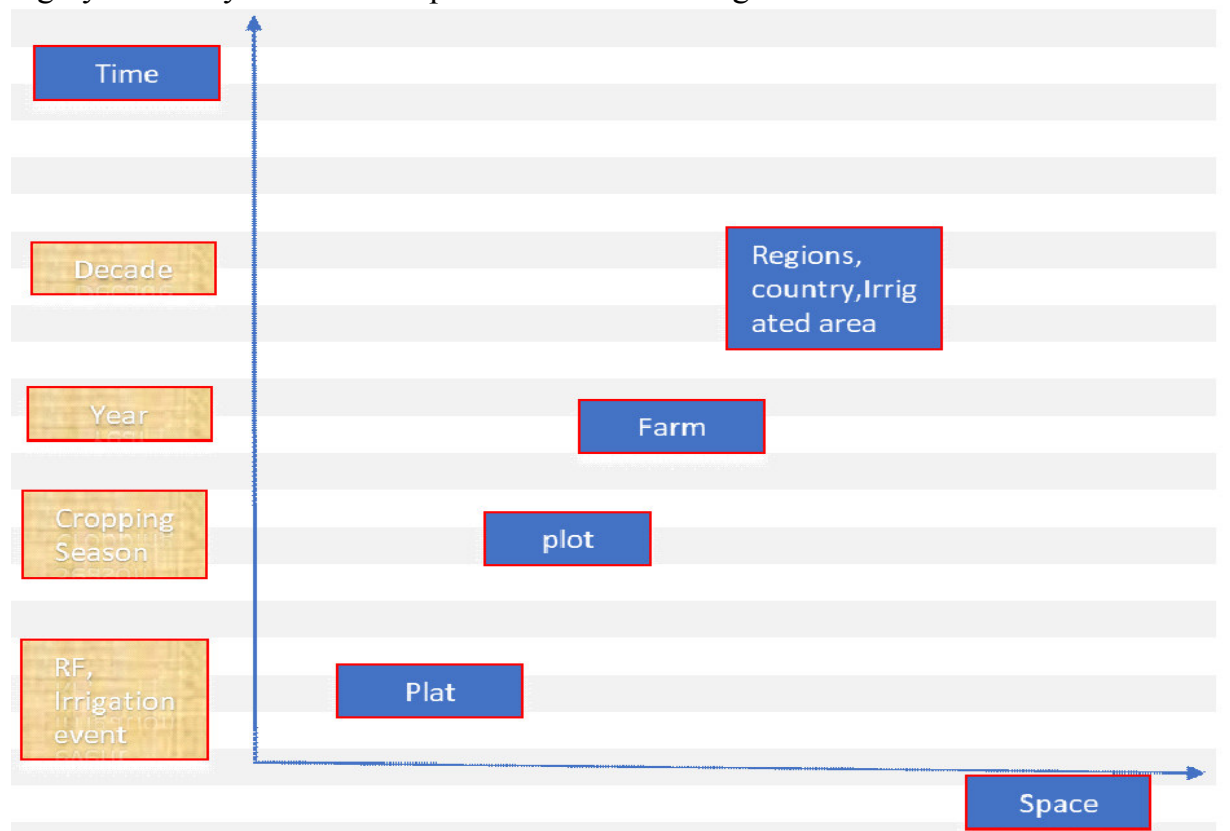

Figure 5. Class of Rainfall Regime of Ethiopia.

iv. Rapid appraisal: this a short field survey to assess the drainage conditions.

During this first step, the need for the second step is assessed. The latter step requires considerable fieldwork and expenditure and should only be undertaken when the preliminary investigations have confirmed that there are sound indications that there are indeed waterlogging and/or salinity problems in the area or in a considerable part of the area, and that these problems are most probably due to a malfunctioning of the drainage systems.

\section{b. Primary Investigation (Second Step)}

This step is followed when there is a major waterlogging and/or salinity problem in the area and these problems are due to a malfunctioning of the drainage systems. In this step, this assumption is confirmed or rejected by collecting indicator data (e.g. water table depth and soil salinity) and comparing these to the accepted standards of good performance. This step may be broken down into two sub-steps:

1. Data collection and processing: monitoring the selected indicator parameters followed by some form of processing to facilitate the use of the collected data.

2. Data evaluation: comparing the collected indicator data with the accepted standards on the basis of which judgments can be made on the performance of the drainage systems. It is of course possible that these Primary Investigations reveal that there is no real waterlogging and salinity in the area or that the prevailing conditions are not due to malfunctioning of the drainage systems. In this case, the observed problems are properly reported and 
the performance assessment of the drainage system is ended. The frequency of investigation for this step depends on the Preliminary Investigation and may be different for each situation. Note that Standard M\&E has been excluded from this description: man-power and funds determine the frequency primarily in that case. Observations of the Standard M\&E collection in step 1 may be used for the peasant association step 2 purpose.

\section{c. Cause Analysis (Third Step)}

This phase is entered when the Primary Investigations have confirmed that the performance of the installed drainage systems doesn't meet the expected standards. The remaining task is then to identify the cause(s) of the underperformance of the system(s). As will be clear from the foregoing, the process of peasant assosoation (PA) of drainage (Figure 3) is shown from the a primarily technical rationale. Moreover, the example suggests an adhoc approach to PA in particular when cause analysis is added to the PA process. This is in practice often the case. In light of the benchmarking of PA, and the service-oriented definition of peasant association, it should be evident that the process should be much more structural and systematically approached in a water management organization.

\section{Management Options to Enhance Soil and Crop Productivity under Poor Drainage Performance. a. Manageent of soil salinity in a potencial plot level and irrigation schemes}

\section{Soil Sample collection}

Salt concentration in soils may vary greatly with horizontal or vertical distance. Hence, a fresh soil profile of standard dimensions will be opened on each selected profile sampling site. The soil profiles will then be described in the field for their morphology following standard procedures and soil samples will be collected based on genetic horizons or layers for laboratory analysis of relevant soil physical and chemical properties. Soil sampling will take place from each horizon. Moreover, composite soil samples will be taken from the surface up to $1.2 \mathrm{~m}$ depth (with $0.3 \mathrm{~m}$ interval) according to the determined grid interval. In parallel, for the purpose of bulk density determination, undisturbed soil samples will be collected using core sampler. Then, the soil samples will be bagged, properly labeled, and transported to the laboratory for analysis.

Sample Preparation and Analysis

Collected soil samples has been air dried, grinned to pass through $2 \mathrm{~mm}$ sieve and stored in clean sample box for analysis [26]. Following standard test procedures soil samples analyzed for selected physico-chemical properties. Particle size distribution determined in the laboratory by the modified Bouyoucos hydrometer method [27],

Soil $\mathrm{pH}$ and $\mathrm{EC}$ measured using a digital $\mathrm{pH}$-meter and $\mathrm{EC}$ mater from saturated past extract. Exchangeable bases $\left(\mathrm{Ca}^{2+}, \mathrm{Mg}^{2+}, \mathrm{K}^{+}\right.$and $\left.\mathrm{Na}^{+}\right)$of the soils was extracted by excess ammonium acetate $\left(1 \mathrm{M} \mathrm{NH} \mathrm{NAc}_{4} \mathrm{Ot} \mathrm{pH} 7\right)$ solution. Exchangeable $\mathrm{Ca}^{2+}$ and $\mathrm{Mg}^{2+}$ in the extracts determined by atomic adsorption spectrophotometer while exchangeable $\mathrm{K}^{+}$and $\mathrm{Na}^{+}$in the extracts measured by flame photometer $[28,29]$. CEC $\left(\mathrm{cmol}_{(+)} / \mathrm{kg}\right)$ of the soils determined from the ammonium acetate saturated samples through distillation and measurement of ammonium using the modified Kjeldahl procedure as described by [28]. Finally, PBS \& ESP computed as the percentage of the sum of exchangeable bases and exchangeable $\mathrm{Na}$ to the CEC of the soil, respectively, as follows:

$$
\operatorname{PBS}(\%)=\frac{\text { Exchangeable bases }\left(\mathrm{Ca}^{2+}, \mathrm{Mg}^{2+}, \mathrm{K}^{+}, \text {and } \mathrm{Na}^{+}\right)}{\mathrm{CEC}} * 100
$$

$$
\operatorname{ESP}(\%)=\frac{\text { Exchangeable sodium }\left(\mathrm{Na}^{+}\right)}{\mathrm{CEC}} * 100
$$

Where, concentrations are in $\mathrm{cmol}(+) / \mathrm{kg}$ of soil.

Basic cations $(\mathrm{Ca}, \mathrm{Mg}, \mathrm{Na}$, and $\mathrm{K})$ and anions $\left(\mathrm{Cl}^{-}, \mathrm{SO}_{4}{ }^{2-}, \mathrm{HCO}_{3}{ }^{-}, \mathrm{CO}_{3}{ }^{2-}\right.$ and $\left.\mathrm{NO}_{3}{ }^{-}\right)$also be was measured on a 1: 5 soil-water ratio extract following the methods described by the US Salinity Laboratory Staff [29, 30]. Soluble Ca and $\mathrm{Mg}$ was read using AAS while that of $\mathrm{Na}$ and $\mathrm{K}$ using a flame photometer. Chloride was determined by titrating the extract against $0.1 \mathrm{~N} \mathrm{AgNO}_{3}$ solution using potassium chromate as an indicator and the concentrations of $\mathrm{SO}_{4}{ }^{2-}$ in soils is determined by precipitation as barium sulphate $\left(\mathrm{BaSO}_{4}\right)$. The $\mathrm{CO}_{3}{ }^{-}$and $\mathrm{HCO}_{3}{ }^{2-}$ ions determined by titrating with sulfuric acid $\left(\mathrm{H}_{2} \mathrm{SO}_{4}\right)$ to phenolphthalein and methyl orange endpoints, respectively. Nitrate $\left(\mathrm{NO}_{3}{ }^{-}\right)$ content analyzed as per the methods outlined by [28, 29]. Sodium adsorption ratio (SAR), of the soil solution, is calculated from the concentrations of soluble $\mathrm{Na}, \mathrm{Ca}$, and $\mathrm{Mg}$ as follows:

$$
\mathrm{SA} R=\frac{\mathrm{Na}^{+}}{\sqrt{\frac{\mathrm{Ca}^{2+}+\mathrm{Mg}^{2+}}{2}}}
$$




\section{Classification method}

The soils will be classified into the different salt-affected soil classes based on the criteria established by the US Salinity Laboratory Staff (1954) as given in Table 1 and crop tolerance and their yield potential as influenced by irrigation water and soil salinity as indicated in FAO-56.

Table 1: Classification of salt affected soils based on their chemical properties

\begin{tabular}{|l|l|l|l|}
\hline Salt affected soil type & $\begin{array}{l}\text { Electrical conductivity of } \\
\text { saturation extracts (ECe) at } \\
25^{\circ} \mathrm{C}(\mathrm{mmhos} / \mathrm{cm})\end{array}$ & $\begin{array}{l}\text { Saturation (\%) of cation } \\
\text { exchange capacity with Na } \\
\text { (ESP) }\end{array}$ & $\begin{array}{l}\text { Reaction } \\
\text { (pH value) }\end{array}$ \\
\hline Saline & $>4$ & $<15$ & $<8.5$ \\
Saline sodic & $>4$ & $>15$ & $<8.5$ \\
Sodic (Alkali) & $<4$ & $>15$ & $8.5-10$ \\
Non-saline non-sodic & $<4$ & $<15$ & About neutral \\
\hline
\end{tabular}

Table 2. Crop tolerance and yield potential of selected crops as influenced by irrigation water salinity (ECw) or soil salinity (ECe) [31].

\begin{tabular}{|c|c|c|c|c|c|c|c|c|c|c|}
\hline Crops & $\begin{array}{l}100 \\
\mathrm{ECe}\end{array}$ & $\mathrm{ECw}$ & $\begin{array}{l}90 \\
\text { EC }\end{array}$ & $\mathrm{ECW}$ & $\begin{array}{l}75 \% \\
\mathrm{ECe}\end{array}$ & $\mathrm{ECw}$ & $\begin{array}{l}50 \% \\
\mathrm{ECe}\end{array}$ & $\mathrm{ECW}$ & $\begin{array}{l}0 \% \\
\mathrm{ECe}\end{array}$ & $\mathrm{ECW}$ \\
\hline Barley & 8.0 & 5.3 & 10 & 6.7 & 13 & 8.7 & 18 & 12 & 28 & 19 \\
\hline Cotton & 7.7 & 5.1 & 9.6 & 6.4 & 13 & 8.4 & 17 & 12 & 27 & 18 \\
\hline Sorghum & 6.8 & 4.5 & 7.4 & 5.0 & 8.4 & 5.6 & 9.9 & 6.7 & 13 & 8.7 \\
\hline Wheat & 6.0 & 4.0 & 7.4 & 4.9 & 9.5 & 6.3 & 13 & 8.7 & 20 & 13 \\
\hline Wheat, durum & 5.7 & 3.8 & 7.6 & 5.0 & 10 & 6.9 & 15 & 10 & 24 & 16 \\
\hline Soybean & 5.0 & 3.3 & 5.5 & 3.7 & 6.3 & 4.2 & 7.5 & 5.0 & 10 & 6.7 \\
\hline Groundnut & 3.2 & 2.1 & 3.5 & 2.4 & 4.1 & 2.7 & 4.9 & 3.3 & 6.6 & 4.4 \\
\hline Rice (paddy) & 3.0 & 2.0 & 3.8 & 2.6 & 5.1 & 3.4 & 7.2 & 4.8 & 11 & 7.6 \\
\hline Sugarcane & 1.7 & 1.1 & 3.4 & 2.3 & 5.9 & 4.0 & 10 & 6.8 & 19 & 12 \\
\hline Maize & 1.7 & 1.1 & 2.5 & 1.7 & 3.8 & 2.5 & 5.9 & 3.9 & 10 & 6.7 \\
\hline Bean & 1.0 & 0.7 & 1.5 & 1.0 & 2.3 & 1.5 & 3.6 & 2.4 & 6.3 & 4.2 \\
\hline Tomato & 2.5 & 1.7 & 3.5 & 2.3 & 5.0 & 3.4 & 7.6 & 5.0 & 13 & 8.4 \\
\hline Cabbage & 1.8 & 1.2 & 2.8 & 1.9 & 4.4 & 2.9 & 7.0 & 4.6 & 12 & 8.1 \\
\hline Potato & 1.7 & 1.1 & 2.5 & 1.7 & 3.8 & 2.5 & 5.9 & 3.9 & 10 & 6.7 \\
\hline Sweet potato & 1.5 & 1.0 & 2.4 & 1.6 & 3.8 & 2.5 & 6.0 & 4.0 & 11 & 7.1 \\
\hline Pepper & 1.5 & 1.0 & 2.2 & 1.5 & 3.3 & 2.2 & 5.1 & 3.4 & 8.6 & 5.8 \\
\hline Onion & 1.2 & 0.8 & 1.8 & 1.2 & 2.8 & 1.8 & 4.3 & 2.9 & 7.4 & 5.0 \\
\hline Carrot & 1.0 & 0.7 & 1.7 & 1.1 & 2.8 & 1.9 & 4.6 & 3.0 & 8.1 & 5.4 \\
\hline Alfalfa & 2.0 & 1.3 & 3.4 & 2.2 & 5.4 & 3.6 & 8.8 & 5.9 & 16 & 10 \\
\hline Orange & 1.7 & 1.1 & 2.3 & 1.6 & 3.3 & 2.2 & 4.8 & 3.2 & 8.0 & 5.3 \\
\hline Lettuce & 1.3 & 0.9 & 2.1 & 1.4 & 3.2 & 2.1 & 5.1 & 3.4 & & \\
\hline
\end{tabular}

b. Manageent of irrigation water quality status in selected hotspot smallholder irrigation schemes

\section{Water Sampling and Preparation}

Water samples have been taken from all possible River water sources of irrigation in major irrigated areas. The water sampling was conducted thrice per annum: (i) during the mid of the dry season, (ii) during the mid of the short rainy season, and (iii) during the mid of the main rainy season [32]. An acid-washed and rinsed polyethylene bottle (2-liters) was used to collect irrigation water samples. The samples is transported to the laboratory and analyzed for their chemical composition immediately. Generally, the collection and handling of irrigation water samples was done in accordance with the procedure outlined by the US Salinity Laboratory Staff (1954) as stated in $[26,29]$. Each of the water sampling points was registered using GPS.

\section{Water Sample Analysis}

The collected water samples are subjected to the analysis of $\mathrm{pH}, \mathrm{EC}$, dissolved cations $(\mathrm{Ca}, \mathrm{Mg}, \mathrm{Na}$ and $\mathrm{K}$ ), alkalinity $\left(\mathrm{HCO}_{3}{ }^{-}\right.$and $\left.\mathrm{CO}_{3}{ }^{2-}\right), \mathrm{Cl}^{-}, \mathrm{SO}_{4}{ }^{2-}, \mathrm{NO}_{3}{ }^{-}$and Boron (B) contents in the laboratory. Furthermore, TDS, SAR, $\mathrm{RSC}$, and the adjusted $\mathrm{RNa}$ estimated from the measured parameters. Finally, the quality and suitability of the water for irrigation is evaluated based on the outputs.

$\mathrm{EC}$ and $\mathrm{pH}$ of the water samples is measured in the laboratory within 24 hours using a conductivity meter and a digital $\mathrm{pH}$ meter, respectively. Alkalinity $\left(\mathrm{HCO}_{3}{ }^{-}+\mathrm{CO}_{3}{ }^{2-}\right.$ ions) will be determined by titrating with standard acid ( $\mathrm{pH}$ of 4.5 ) within 12 to 24 hours of sample collection. Chloride was measured by the silver nitrate titrimetric 
method, and $\mathrm{SO}_{4}{ }^{2-}$ determined by the barium sulphate turbid metric or gravimetric method [33]. Nitrate $\left(\mathrm{NO}_{3}{ }^{-}\right)$ analyzed as per the methods outlined by [28] and B was determined following a standard analytical procedure. Ca and $\mathrm{Mg}$ ions were measured using the atomic absorption spectrophotometer, whilst $\mathrm{Na}$ and $\mathrm{K}$ was analyzed using a flame photometer.

Irrigation water salinity, as total dissolved salts (TDS), were determined by summing the concentration of the individual ions $[34,35]$. Moreover, for solutions in the EC range of 0.1 to $5.0 \mathrm{mmhos} / \mathrm{cm}$, the TDS (mg/l or $\mathrm{ppm}$ ) may be obtained by multiplying the EC value expressed in mmhos/cm by 640 . The SAR value is calculated using equation (4) with the concentrations expressed in meq/l. The residual sodium carbonate (RSC) determined from the concentrations of $\mathrm{HCO}_{3}{ }^{-}, \mathrm{CO}_{3}{ }^{2-}, \mathrm{Ca}^{2+}$, and $\mathrm{Mg}^{2+}$ ions as follows:

$$
\mathrm{RSC}=\left[\left(\mathrm{HCO}_{3}{ }^{-}+\mathrm{CO}_{3}{ }^{2-}\right)-\left(\mathrm{Ca}^{2+}+\mathrm{Mg}^{2+}\right)\right]
$$

Where, concentrations are expressed in meq/l (US Salinity Laboratory Staff, 1954). Adjusted RNa (adj. $R_{N a}$ ), which is recommended by Suarez (1981) as more acceptable than adjusted SAR and represents the true picture of the SAR will be calculated as:

$$
\operatorname{Adj} . \mathrm{R}_{\mathrm{Na}}=\frac{\left[\mathrm{Na}^{+}\right]}{\sqrt{\frac{\mathrm{Ca}_{\mathrm{X}}^{2+}+\mathrm{Mg}^{2+}}{2}}}
$$

Where; $\mathrm{Na}$ is the concentration of $\mathrm{Na}$ in the irrigation water expressed in meq/l, $\mathrm{Ca}_{\mathrm{x}}$ is a modified.

$\mathrm{Ca}$ value presented in Table 11 (page 62) of FAO Paper 29 Rev. 1 (FAO, 1989) reported in meq/l. Ca $\mathrm{a}_{\mathrm{x}}$ represents $\mathrm{Ca}$ in the irrigation water but modified due to salinity of the water $\left(\mathrm{EC}_{\mathrm{iw}}\right)$, its $\mathrm{HCO}_{3} / \mathrm{Ca}$ ratio $\left(\mathrm{HCO}_{3}\right.$ and $\mathrm{Ca}$ in $\mathrm{meq} / \mathrm{l})$ and the estimated partial pressure of $\mathrm{CO}_{2}$ in the surface few $\mathrm{mm}$ of soil $\left(\mathrm{P}_{\mathrm{CO} 2}=0.0007\right.$ atmospheres $)$ and $\mathrm{Mg}$ is the concentration of $\mathrm{Mg}$ in the irrigation water expressed in meq/l.

\begin{tabular}{|c|c|c|c|c|}
\hline \multirow{5}{*}{$\begin{array}{c}\text { Potential irrigation problem } \\
\text { Salinity: (affecting crop) } \\
\text { ECw } \backslash\end{array}$} & \multirow{3}{*}{ Units } & \multicolumn{3}{|c|}{ Degree of restriction on use } \\
\hline & & \multicolumn{2}{|c|}{ None Slight to moderate } & \multirow[t]{2}{*}{ Severe } \\
\hline & & & & \\
\hline & $\mathrm{dS} \mathrm{m}^{-1}$ & $<0.7$ & $0.7-3.0$ & $>3.0$ \\
\hline & & & & \\
\hline TDS ${ }^{\text {or }}$ & $\operatorname{mg~} \operatorname{lt}^{-1}$ & $<450$ & -2000 & $>2000$ \\
\hline \multicolumn{5}{|l|}{ Infiltration (affecting soil) } \\
\hline $\mathrm{SAR}=0-3$ and $\mathrm{ECW}=$ & & $>0.7$ & $0.7-0.2$ & $<0.2$ \\
\hline$=3-6=$ & & $>1.2$ & $1.2-0.3$ & $<0.3$ \\
\hline$=6-12$ & & $>1.9$ & $1.9-0.5$ & $<0.5$ \\
\hline$=12-20$ & & $>2.9$ & $2.9-1.3$ & $<1.3$ \\
\hline$=20-40 \quad=$ & & $>5.0$ & $5.0-2.9$ & $<2.9$ \\
\hline \multicolumn{5}{|l|}{$\begin{array}{l}\text { Specific ion toxicity } \\
\text { (affects sensitive crop) }\end{array}$} \\
\hline \multirow{2}{*}{$\begin{array}{ll}\text { Sodium }(\mathrm{Na}) & \text { surface } \\
& \text { Sprinkler }\end{array}$} & SAR & $<3$ & $3-9$ & $>9$ \\
\hline & me $1 t^{-1}$ & $<3$ & $>3$ & \\
\hline \multirow{2}{*}{$\begin{aligned} \text { Chloride ( C ) } \begin{array}{l}\text { Surface } \\
\text { Sprinkler }\end{array}\end{aligned}$} & me $1 t^{-1}$ & $<4$ & $4-10$ & $>10$ \\
\hline & me $1 t^{-1}$ & $<3$ & $>3$ & \\
\hline Boron ( B ) & me $1 t^{-1}$ & $<0.7$ & $0.7-3.0$ & $>3.0$ \\
\hline \multicolumn{5}{|l|}{$\begin{array}{l}\text { Miscellaneous effect } \\
\text { (Affect susceptabe crops) }\end{array}$} \\
\hline Nitrogen $\left(\mathrm{NO}_{3}-\mathrm{N}\right)$ & me $1 t^{-1}$ & $<5$ & $5-30$ & $>30$ \\
\hline $\begin{array}{l}\text { Bicarbonate }\left(\mathrm{HCO}_{3}\right) \\
\text { (overhead sprinkling only) }\end{array}$ & me $1 t^{-1}$ & $<1.5$ & $1.5-8.5$ & $>8.5$ \\
\hline $\mathrm{pH}$ & & Norma & ge $6.5-8.4$ & \\
\hline
\end{tabular}

Table 3. Guidelines for evaluating irrigation water quality

\section{c. Determination \& Measurement of Irrigation water in the field and irrigation scheme level.}

The depth of irrigation water which can be given during one irrigation application is however limited. The maximum depth which can be given has to be determined and may be influenced by the soil type and the root zone depth.

Once it is determined that after how many days the crop should be irrigated then the amount of irrigation to be applied can be computed by working out the daily evapotranspiration rate of the crop to be irrigated.

$\mathbf{E T c}=$ ETo x Kc

where, $\mathrm{ETc}=$ Evapotranspiration rate of the crop $\mathrm{mm} /$ day; ETo $=$ Reference evapotranspiration rate $\mathrm{mm} /$ day and Kc $=$ Crop co-efficient. 
ETc can be calculated by a number of methods, most popular being the Penman-Monteith Method using local agro-meteorological data. Tables are available which contains $\mathrm{Kc}$ values of common crops for different growth stages and for different climate regions. Once ETo and Kc Values are known then it is simple multiplication to calculate daily evapotranspiration (ETc). Then daily ETc is multiplied with the number of days the crop is to be irrigated, to find out the amount of irrigation to be applied.

Step-wise computation of irrigation scheduling for a particular crop

To compute proper irrigation scheduling for crops, it is necessary to know the type of crop, growth stage, effective root zone, available water holding capacity of the soil, and daily evapotranspiration rate (ETc) of the crop. Then follow the procedure given below step by step to compute irrigation scheduling.

Step 1. Compute ETo and obtain appropriate Kc-values to get daily ETcrop demand

Step 2. Find out the root zone depth at different growth stages

Step 3. Find out the Total Avaliable Soil Water (TASW) in the root zone for the respective growth stages

Step 4. Find out Manageable Allowable Depilation (MAD)

Step 5. Divide step 4 by daily ETcrop (step 1), this will give irrigation interval in days

Step 6. Multiply step 5 with ETcrop (step 1). This will give net irrigation requirements for the given growth stage

Step 7. Divide step 6 with application efficiency, Ea. This will give gross irrigation requirement, IRg.

Step 8. Find out additional irrigation water requirement for leaching out the soil, if needed from:

$$
\text { Dw }=\frac{\text { IRn }}{1-\mathrm{LR}} \quad \ldots . . . . . . . . . . . .(7) \quad \text { where, } \quad \text { LR }=\frac{\mathrm{ECw}}{5 \mathrm{ECe}-\mathrm{ECw}}
$$

Once irrigation interval and amount is fixed, it is a matter of computing the discharge and time required to refill the soil moisture. The time required to refill the soil moisture can be obtained from the following relationship:

$$
\mathbf{T}=\frac{\mathbf{D w}}{\mathbf{I}}
$$

Where, $\mathrm{T}$ is time required to refill the soil moisture depleted in hrs, Dw is the depth of irrigation water to be applied in $\mathrm{mm}$ and $\mathrm{I}$ is infiltration rate of the soil in $\mathrm{mm} \mathrm{hr}^{-1}$.

Table 4. Infiltration rates (I) related to soil texture

\begin{tabular}{|l|l|l|l|}
\hline Soil texture & $\begin{array}{l}\text { Representative I } \\
\left(\mathrm{mm} \mathrm{hr}^{-1}\right)\end{array}$ & $\begin{array}{l}\text { Normal range of I } \\
\left(\mathrm{mm} \mathrm{hr}^{-1}\right)\end{array}$ & Category \\
\hline Sandy & 50 & $20-250$ & Rapid \\
\hline Sandy loam & 20 & $10-80$ & Moderate rapid \\
\hline Loam & 10 & $10-20$ & Moderate \\
\hline Clay loam & 8 & $2-15$ & Moderately slow \\
\hline Silty clay & 2 & $0.3-5$ & Slow \\
\hline Clay & 0.5 & $0.1-8$ & Very slow \\
\hline
\end{tabular}

Source: Israelsen and Hansen (1962)

The discharge rate, $\mathrm{Q}$, for a particular field can be obtained from:

$$
Q(1 / s)=\frac{A * d}{T * 3600}
$$

Where, $\mathrm{Q}$ is in lt./sec, $\mathrm{A}$ is area to be irrigated in $\mathrm{m}^{2}, \mathrm{~d}$ in $\mathrm{mm}$ and $\mathrm{T}$ in $\mathrm{hr}$

\section{Flow measurement using Parshal Flume}

A parshall flume consists of three sections, namely, the converging section, the throat $\&$ the diverging section. The converging section has a level floor \& vertical walls converging towards the throat. The walls of the throat are parallel \& the floor in inclined downwards. The walls of the diverging section are vertical \& diverging outwards $\&$ the floor is inclined upwards.

\section{a. Installation procedure:}

1. Straight section of the channel $(10 \mathrm{~m})$ should be selected.

2. Install at 3 to $4 \mathrm{~m}$ from the downstream side.

3. It should be placed parallel to the channel $\&$ to the direction of water flow.

4. The entrance section should be about $3-5 \mathrm{~cm}$ above the channel bed.

5. A line level should be used to check the level of the top \& floor of the entrance section at the time of installation \& periodically.

6. Earth should be filled between the wall of the flume \& the channel sidewalls. Avoid any leakage through the side.

\section{b. Recording of the reading:}

1. Divert the water in the channel where water flow has to be measured $\&$ where the Parshall flume has been installed.

2. Allow the water to flow through the Parshall flume \& leave the flow to assume a steady state.

3. Record the reading every $10-15$ minutes. If the flow is found to be constant, reading can be done at 30 
minutes intervals.

4. The flow rate (discharge) is measured by liter per second ( $1 / \mathrm{s})$, the area of the plot/field to be irrigated is measured by the square meter $\left(\mathrm{m}^{2}\right)$ and the depth of water to be irrigated $(\mathrm{d})$ is measured by centimeter (cm).

Time Required (T) (min.) $=A^{*} \mathbf{d} / 6 * q$

Table 5. Discharge (1/s) for Parshall flumes of various throat widths.

\begin{tabular}{|c|c|c|c|c|c|}
\hline \multirow[t]{2}{*}{ Head (cm) } & \multicolumn{5}{|c|}{ Throat Width Inch (cm) } \\
\hline & $1 "(2.5 \mathrm{~cm})$ & $2 "(5 \mathrm{~cm})$ & $3 "(7.5 \mathrm{~cm})$ & $6 "(15 \mathrm{~cm})$ & $9 "(23 \mathrm{~cm})$ \\
\hline & \multicolumn{5}{|c|}{ Discharge (1/s) } \\
\hline 2 & 0.140 & 0.281 & & & \\
\hline 3 & 0.263 & 0.526 & 0.772 & 1.496 & 2.504 \\
\hline 4 & 0.411 & 0.822 & 1.206 & 2.357 & 3.889 \\
\hline 5 & 0.581 & 1.162 & 1.705 & 3.354 & 5.471 \\
\hline 6 & 0.771 & 1.541 & 2.261 & 4.473 & 7.232 \\
\hline 7 & 0.979 & 1.957 & 2.872 & 5.707 & 9.155 \\
\hline 8 & 1.205 & 2.407 & 3.532 & 7.047 & 11.231 \\
\hline 9 & 1.446 & 2.889 & 4.239 & 8.489 & 13.448 \\
\hline 10 & 1.702 & 3.402 & 4.991 & 10.027 & 15.801 \\
\hline 11 & 1.973 & 3.943 & 5.786 & 11.656 & 18.281 \\
\hline 12 & 2.258 & 4.513 & 6.621 & 13.374 & 20.885 \\
\hline 13 & 2.557 & 5.109 & 7.496 & 15.177 & 23.605 \\
\hline 14 & 2.868 & 5.731 & 8.408 & 17.062 & 26.440 \\
\hline 15 & 3.191 & 6.377 & 9.358 & 19.027 & 29.383 \\
\hline 16 & 3.527 & 7.048 & 10.342 & 21.070 & 32.433 \\
\hline 17 & 3.875 & 7.743 & 11.361 & 23.188 & 35.585 \\
\hline 18 & 4.234 & 8.460 & 12.413 & 25.38 & 38.837 \\
\hline 19 & 4.604 & 9.200 & 13.499 & 27.643 & 42.186 \\
\hline
\end{tabular}

\section{Beneficiaries and Impacts}

Over $85 \%$ of the population, involved in agricultural production, and more than $9 \%$ of the population lives in the areas affected by salinity, and severity is highly increasing. Therefore, mainly farmers, commercial farmers, suppliers, processors and exporters of agricultural products, NGOs, etc... will be benefited from the results of this. Above all, it is believed that it would contribute a lot towards the future development strategy of the country in a way of poverty reduction, food self-sufficiency, conservation of natural resources and environemnt, and alleviation of climate changes.

\section{Conclusions}

Some earlier studies identified salt-affected surfaces have increased from $6 \%$ to $16 \%$ of the total land of Ethiopia in recent years. About $9 \%$ of the population lives in the areas affected by salinity. The semi-arid and arid lowlands and valleys in Ethiopia have major problems of salinity and alkalinity. About 44 million ha in $36 \%$ of the country's total land is potentially susceptible to salinity problems. According to recent researches, out of the 44 million ha, 33 million ha has dominantly salinity problems, 8 million ha has combined salinity and alkalinity problems, and 3 million ha has dominantly alkalinity problems. Majority of schemes (small, medium and large), poor drainage facilities and water management practices, hence, give low yields (quite below the national average) with poor 
crop quality and environmental damage. Such a very low yield, poor crop quality and salinity could be attributed to poor drainage system under schemes. Hence, improved and proper management and application of irrigation water can easily combat soil salinity and protect the environment. Besides, it can improve productivity and quality of crop yield in the potential areas of the country.

\section{Acknowledgement}

The author is grateful to National Irrigation and Drainage Research Program, Ethiopian Institute of Agricultural Research, for providing funds for the experiment and technical support. They are thankful for technical and field assistance for their technical assistance in the field data assesement.

\section{Conflicts of interest}

The authors declare there is no conflict of interest.

\section{References}

1. Hagos F, M.G., Namara RE, Awulachew SB Importance of irrigated agriculture to the Ethiopian economy: Capturing the direct net benefits of irrigation. International Water Management Institute, 2009: p. pp. 37.

2. Smith, C. and G. McDonald, Assessing the sustainability of agriculture at the planning stage. Journal of environmental management, 1998. 52(1): p. 15-37.

3. Abera, A., et al., Performance of small-scale irrigation schemes in Lake Tana Basin of Ethiopia: technical and socio-political attributes. Physical Geography, 2019. 40(3): p. 227-251.

4. Haile, G.G. and A.K. Kasa, Irrigation in Ethiopia: A review. Academia Journal of Agricultural Research, 2015. 3(10): p. 264-269.

5. MoWIE, Water Resources of Ethiopia; The National and International Perspective, Awareness creation Program prepared for Public Relation officials. 2013.

6. Singh, A., Hydrological problems of water resources in irrigated agriculture: A management perspective. Journal of Hydrology, 2016. 541: p. 1430-1440.

7. Makombe, G., et al., A comparative analysis of the technical efficiency of rain-fed and smallholder irrigation in Ethiopia. Vol. 143. 2011: IWMI.

8. Awulachew, S.B., et al. Roles, constraints and opportunities of small scale irrigation and water harvesting in Ethiopian agricultural development: Assessment of existing situation. in ILRI workshop. 2010.

9. MoA, Natural Resources Management Directorates. Small-Scale Irrigation Situation Analysis and Capacity Needs Assessment. 2011a.

10. Molden, D., M. Burton, and M. Bos, Performance assessment, irrigation service delivery and poverty reduction: benefits of improved system management. Irrigation and Drainage: The journal of the International Commission on Irrigation and Drainage, 2007. 56(2 - 3): p. 307-320.

11. Berhanu, B., et al., Bias correction and characterization of climate forecast system re - analysis daily precipitation in Ethiopia using fuzzy overlay. Meteorological Applications, 2016. 23(2): p. 230-243.

12. Allison, L.E. and L.A. Richards, Diagnosis and improvement of saline and alkali soils. 1954: Soil and Water Conservative Research Branch, Agricultural Research Service ....

13. Carter, D.L., Problems of salinity in agriculture, in Plants in saline environments. 1975, Springer. p. $25-$ 35.

14. Gebrehiwot, K.A., A review on waterlogging, salinization and drainage in Ethiopian irrigated agriculture. Sustainable Water Resources Management, 2018. 4(1): p. 55-62.

15. Jouni, H.J., et al., Managing controlled drainage in irrigated farmers' fields: A case study in the Moghan plain, Iran. Agricultural Water Management, 2018. 208: p. 393-405.

16. Singh, A., Environmental problems of salinization and poor drainage in irrigated areas: Management through the mathematical models. Journal of Cleaner Production, 2019. 206: p. 572-579.

17. Harris, N.M., et al., Classification of river regimes: a context for hydroecology. Hydrological Processes, 2000. 14(16 - 17): p. 2831-2848.

18. Dawit, E.L., Paleoclimatic records of Late Triassic paleosols from Central Ethiopia. Palaeogeography, Palaeoclimatology, Palaeoecology, 2016. 449: p. 127-140.

19. MoWR, Irrigation Development Strategy (Component of the Water Sector Development Strategy). . 2001.

20. Werfring, A., Typology of irrigation in Ethiopia. 2004.

21. MoWR, Ethiopia: Managing Water Resources to Maximize Sustainable Growth, Country Water Resources Assistance Strategy. 2006: p. pp.99.

22. MoA, Natural Resources Sector, Small-Scale Irrigation Capacity Building Strategy for Ethiopia. 2011 b.

23. Rhoades, J., Drainage for salinity control. Drainage for agriculture, 1974. 17: p. 433-461. 
24. Valipour, M., Drainage, waterlogging, and salinity. Archives of Agronomy and Soil Science, 2014. 60(12): p. 1625-1640.

25. Singh, A., Salinization of agricultural lands due to poor drainage: A viewpoint. Ecological Indicators, 2018. 95: p. 127-130.

26. Jackson, M.L., Soil chemical analysis: Advanced course. 2005: UW-Madison Libraries Parallel Press.

27. Bouyoucos, G.J., Hydrometer method improved for making particle size analyses of soils 1. Agronomy journal, 1962. 54(5): p. 464-465.

28. Okalebo, J., K. Gathua, and P. Woomer, Laboratory methods of soil and plant analysis. A working manual, 2002. 2: p. 29-68.

29. Rayment, G.E. and D.J. Lyons, Soil chemical methods: Australasia. Vol. 3. 2011: CSIRO publishing.

30. Ryan, J., G. Estefan, and A. Rashid, Soil and plant analysis laboratory manual. 2001: ICARDA.

31. Allen, R.G., et al., Crop evapotranspiration-Guidelines for computing crop water requirements-FAO Irrigation and drainage paper 56. Fao, Rome, 1998. 300(9): p. D05109.

32. Hopkins, B.G., et al., Managing irrigation water quality for crop production in the Pacific Northwest. 2007.

33. Nishanthiny, S.C., et al., Irrigation water quality based on hydro chemical analysis, Jaffna, Sri Lanka. Am Eurasian J Agric Environ Sci, 2010. 7(1): p. 100-102.

34. Wilcox, L., Classification and use of irrigation waters. 1955: US Department of Agriculture.

35. Wood, R. and J. Talling, Chemical and algal relationships in a salinity series of Ethiopian inland waters, in Saline Lakes. 1988, Springer. p. 29-67. 